\title{
Internalization of Aeromonas hydrophila by fish epithelial cells can be inhibited with a tyrosine kinase inhibitor
}

\author{
E. Tan, ${ }^{1}$ K. W. Low, ${ }^{1}$ W. S. F. Wong ${ }^{2}$ and K. Y. Leung ${ }^{1}$ \\ Author for correspondence: K. Y. Leung. Tel: +65 8747835. Fax: +65 7792486. \\ e-mail: sbslky@nus.edu.sg
}

School of Biological Sciences, Faculty of Science ${ }^{1}$, and Department of Pharmacology, Faculty of Medicine², National University of Singapore, 10 Kent Ridge Crescent, Singapore 119260

\begin{abstract}
Aeromonas hydrophila is a Gram-negative bacterium that is pathogenic in fish, causing motile aeromonad septicaemia. It can enter (invade) fish cells, and survive as an intracellular parasite. The host-pathogen interaction and signal transduction pathway were studied by screening signal transduction inhibitors using carp epithelial cells and a virulent strain of the bacterium, PPD134/91. Genistein, a tyrosine kinase inhibitor, postponed internalization of $A$. hydrophila into host cells, suggesting that tyrosine phosphorylation plays a role in internalization. In contrast, staurosporine, a protein kinase $\mathrm{C}$ inhibitor, and sodium orthovanadate, a protein tyrosine phosphatase inhibitor, accelerated internalization of PPD134/91. Other virulent strains of $A$. hydrophila were also examined and it is likely that all strains, irrespective of serogroup, use the same signalling pathway to facilitate bacterial uptake.
\end{abstract}

Keywords: tyrosine kinase, Aeromonas hydrophila, fish epithelial cells

\section{INTRODUCTION}

Aeromonas bydrophila is the causative agent of motile aeromonad septicaemia, found in a wide variety of freshwater fish species (Newman, 1993; Thune et al., 1993). Motile aeromonad septicaemia outbreaks are common all over the world, and have been reported in Australia (Burke \& Rogers, 1981), the south-eastern states of America (Pippy \& Hare, 1969), Spain (Nieto et al., 1985) and the Southeast Asia region (Roberts et al., 1992). Outbreaks of motile aeromonad septicaemia usually occur only when the fish are immunocompromised by stresses such as overcrowding or concurrent disease (Stevenson, 1988). A. hydrophila produces several virulence determinants, including cytotoxins and enterotoxins (Ljungh \& Wadstrom, 1982; Yadav et al., 1992) and a repertoire of enzymes that digest cellular components, mostly proteases and haemolysins (Allan \& Stevenson, 1981; Leung \& Stevenson, 1988). Other virulence factors such as the $S$ layer (Dooley \& Trust, 1988) and serum resistance (Mittal et al., 1980; Leung et al., 1995) are also implicated in aiding bacterial resistance to attack by the host's non-specific immune mechanisms.

A prerequisite for the initiation of infection is the initial

Abbreviation: EPC, epithelioma papillosum of carp. adherence to, and invasion of, host epithelial cells. $A$. bydrophila is able to attach to collagen, fibronectin, serum proteins and glycoproteins found in fish mucus and epithelial cells (Atkinson \& Trust, 1980; Ascencio et al., 1991; Neves et al., 1994). The putative adhesins thought to facilitate attachment may provide the necessary anchorage for the bacteria to facilitate subsequent invasion. We have recently studied the interaction between several different fish cell cultures and $A$. bydrophila and reported that A. bydrophila can enter into these cells and induce morphological changes (Leung et al., 1996; Low et al., 1998).

Invasion of cells by bacterial pathogens involves adherence of the organism to the host cell, followed by bacterial internalization into a membrane-bound vacuole inside the host cell (Moulder, 1985; Finlay \& Falkow, 1989). Once inside the cell, these bacteria either remain within membrane-bound inclusions, as does Salmonella typhimurium, which multiplies efficiently within vacuoles (Garcia-del Portillo et al., 1993), or escape into the cytoplasm, as does Shigella flexneri, which encodes enzymes to lyse the vacuolar membrane (Hale \& Boventre, 1979).

Entry into non-phagocytic cells involves triggering host signal transduction mechanisms to induce rearrangements of the host cytoskeleton, thereby facilitating 
bacterial uptake (Finlay et al., 1991; Pace et al., 1993; Rosenshine \& Finlay, 1993; Rosenshine et al., 1996). Initiation of cytoskeletal rearrangement by enteropathogenic Escherichia coli appears to be triggered by activation of specific host tyrosine kinase activity. The induction of tyrosine kinase activity is mediated by the products of the enteropathogenic E. coli $\mathrm{cfm}$ genes. Enteropathogenic $E$. coli also causes an increase in the level of intracellular free calcium (Rosenshine et al., 1992a). For Yersinia species, invasin interacts with host integrins, causing the clustering of integrin into focal points, which possibly triggers host tyrosine kinase activity that may result in host cytoskeletal rearrangements (Young et al., 1992). Thus, activation of tyrosine kinase appears to be a common feature in the signal transduction pathway of invasive pathogens leading to internalization.

The surface characteristics, virulence factors and distribution of $A$. hydrophila have been extensively studied. However, the interaction between the host and $A$. bydrophila remains largely unknown. In this work, we aimed to examine the interaction between $A$. bydropbila and carp epithelial cells. By using inhibitors of potential components of signal transduction pathways, it was hoped that the signalling pathway mediating internalization could be elucidated and thus that the pathogenesis of A. hydrophila would be better understood.

\section{METHODS}

Bacterial strains. Three virulent strains of A. hydrophila were used in this study (Leung et al., 1995). A. bydrophila PPD134/91, PPD122/91 and PPD11/90 were isolated from diseased fish by the Primary Production Department of Singapore. They were tested using standard biochemical diagnostic kits (Microbact 24E System, Medvet Science; and BBL Crystal Enteric/Nonfermenter ID System, Becton Dickinson), and their identities were confirmed according to the criteria of Popoff (1984). Cultures were routinely grown in tryptic soy broth (TSB; Difco) or on tryptic soy agar (TSA; Difco) at $25^{\circ} \mathrm{C}$. Stock cultures were maintained at $-80^{\circ} \mathrm{C}$ as a suspension in TSB containing $25 \%(\mathrm{v} / \mathrm{v})$ glycerol.

Cell cultures. All tissue culture reagents were obtained from Gibco. EPC cells (epithelioma papillosum of carp, Cyprinus carpio) (Wolf \& Mann, 1980) were grown in minimal essential medium (MEM) with Hanks' salts, $10 \mathrm{mM}$ HEPES ( $\mathrm{pH} 7 \cdot 3$ ), $2 \mathrm{mM}$ glutamine, $0 \cdot 23 \% \mathrm{NaHCO}_{3}$ and $10 \%$ heat-inactivated foetal bovine serum at $25{ }^{\circ} \mathrm{C}$ in a $5 \% \mathrm{CO}_{2}$ atmosphere. Cells were grown in $75 \mathrm{~cm}^{2}$ flasks and split at least once a week by trypsin/EDTA treatment and dilution at $1: 10$ in fresh media.

Confocal microscopy. The Live/Dead BacLight Viability kit (Molecular Probes) was used to fluorescently label bacteria. NBD-phallacidin (Molecular Probes) was used to reveal the Factin structure. EPC cells were seeded on glass coverslips and infected with $A$. bydrophila as described below. Coverslips were examined using a Nikon Optiphot microscope attached to the Bio-Rad MRC 500 confocal system (Lasersharp). Confocal images obtained under argon laser $488 \mathrm{~nm}$ blue excitation were photographed with a Polaroid Freeze-frame recorder using Kodak Tmax 100 film.

Signal transduction inhibitors. Inhibitors and their concentrations used are listed in Table 1 . The solvent used to dissolve all chemicals was DMSO, except for sodium orthovanadate, which was dissolved in deionized water. Before use, the inhibitors were further diluted in MEM supplemented with $10 \%(\mathrm{v} / \mathrm{v})$ foetal bovine serum and this was added to the cultured EPC cells. The concentrations of inhibitors used were according to the manufacturers' recommendations. For gen-

Table 1. Classes of inhibitors used

\begin{tabular}{|c|c|c|c|}
\hline Class & $\begin{array}{l}\text { Specific } \\
\text { inhibitor }\end{array}$ & Concn used $(\mu \mathrm{M})$ & $\begin{array}{l}\text { Time taken for infected } \\
\text { EPC cells to reach } \\
\text { stage II morphology } \\
(\text { min })^{*}\end{array}$ \\
\hline Control & - & - & $58 \cdot 3 \pm 2 \cdot 9$ \\
\hline \multirow[t]{4}{*}{ Protein tyrosine kinase inhibitors } & Genistein & $50,100,150,200,250 \dagger$ & $96 \cdot 7 \pm 2 \cdot 9 \ddagger$ \\
\hline & Herbimycin A & 10 & $58 \cdot 3 \pm 3 \cdot 0$ \\
\hline & Tyrphostin 47 & $50,100 \dagger$ & $60 \cdot 7 \pm 4 \cdot 9$ \\
\hline & Tyrphostin & 50,100 & $60 \cdot 7 \pm 4 \cdot 9$ \\
\hline Genistein analogue & Daidzein & 150 & $61 \cdot 7 \pm 2 \cdot 9$ \\
\hline Protein tyrosine phosphatase inhibitor & $\begin{array}{l}\text { Sodium } \\
\text { orthovanadate }\end{array}$ & 10 & $52 \cdot 3 \pm 2 \cdot 9 \neq$ \\
\hline \multirow[t]{2}{*}{ Protein kinase $\mathrm{C}$ inhibitors } & Staurosporine & $0 \cdot 005$ & $50 \cdot 0 \pm 5 \cdot 0 \ddagger$ \\
\hline & Calphostin C & 0.5 & $63 \cdot 7 \pm 8 \cdot 1$ \\
\hline \multirow[t]{2}{*}{ Protein phosphatase inhibitors } & Okadaic acid & $0 \cdot 1$ & $61 \cdot 5 \pm 3 \cdot 5$ \\
\hline & Calyculin A & $0.0001,0.001,0.002 \dagger$ & $57 \cdot 0 \pm 1 \cdot 4$ \\
\hline \multirow[t]{2}{*}{$\mathrm{Ca}^{2+}$ channel blockers } & Nifedipine & $0 \cdot 1,1 \dagger$ & $62 \cdot 3 \pm 6 \cdot 6$ \\
\hline & Verapamil $\mathrm{HCl}$ & $1,10 \dagger$ & $58 \cdot 7 \pm 4 \cdot 0$ \\
\hline
\end{tabular}

*Values shown are the mean $\pm S D$ from duplicate wells in three separate experiments.

† Concentrations used for the effect on infected EPC cells.

$\ddagger$ Those inhibitors where the time taken to reach stage II was significantly different from the control $(P<0.05)$. 
istein and staurosporine, concentrations used were those described by Rosenshine et al. (1992a).

Effect of inhibitors on the morphological changes and viabilities in EPC and bacteria. Studies on morphological changes were conducted by seeding $3 \times 10^{5}$ fish cells into each well of a 24-well tissue culture plate (Falcon) and proceeding as described by Leung et al. (1996). Briefly, $5 \mathrm{ml}$ stationaryphase cultures were prepared by inoculating TSB with $A$. bydrophila from frozen glycerol stocks and incubating overnight at $25^{\circ} \mathrm{C}$. Three hours before infection of cells, midexponential-phase cultures were prepared by diluting the bacteria $1: 20$ in fresh TSB and incubating at $25^{\circ} \mathrm{C}$ for $2.5 \mathrm{~h}$. Bacterial cells were pelleted and washed three times in PBS (137 mM NaCl, 2.7 mM KCl, 4.3 $\mathrm{mM} \mathrm{Na}_{2} \mathrm{HPO}_{4}$ and $1.4 \mathrm{mM}$ $\mathrm{KH}_{2} \mathrm{PO}_{4}$ at $\mathrm{pH} 7 \cdot 2$ ) before adding $5 \mu \mathrm{l}$ to each tissue culture well (approximately $5 \times 10^{5}$ bacteria). After inoculation, the 24-well tissue culture plate was centrifuged $(800 \mathrm{~g}, 5 \mathrm{~min}$, $4{ }^{\circ} \mathrm{C}$ ), then incubated for $30 \mathrm{~min}$ at $25^{\circ} \mathrm{C}$. Infected monolayers were washed once with MEM and then incubated in fresh, supplemented MEM. The morphology of EPC cells was examined every $5 \mathrm{~min}$ using an Axiovert 25CFL phasecontrast inverted microscope (Carl Zeiss) at $\times 200$ magnification. In studies of different signal transduction inhibitors, EPC cells were incubated with the inhibitor for $30 \mathrm{~min}$ before bacterial infection. The time taken to reach each morphological stage was determined from duplicate wells in three separate experiments.

To investigate if the inhibitors could halt the morphological changes of previously infected EPC cells, the monolayers were first infected with bacteria for 5, 10, 15, 20, 30 and $45 \mathrm{~min}$ before the addition of inhibitors. To investigate if the effects of the inhibitors on EPC cells were reversible, the monolayers were incubated with the inhibitors for $30 \mathrm{~min}$, and then washed twice with MEM to remove the inhibitors before infection with the bacteria.

To ensure that the inhibitors did not affect EPC cells, the cells were grown for $3 \mathrm{~h}$ in MEM containing genistein $(250 \mu \mathrm{M})$, staurosporine $(0.005 \mu \mathrm{M})$ or sodium orthovanadate $(10 \mu \mathrm{M})$. A trypan blue exclusion assay was then used to determine whether treated EPC cells had similar viability to the untreated control. Similarly, A. bydrophila was treated with each of these three inhibitors for $3 \mathrm{~h}$. Bacterial viability counts were determined before and after the $3 \mathrm{~h}$ incubation period. EPC and bacterial viabilities were determined by doing each experiment in triplicate.

Internalization assay. The invasion assay was as described by Leung \& Finlay (1991) with minor modifications. Briefly, a monolayer of EPC cells was grown for $72 \mathrm{~h}$ in 24-well tissue culture plates to $100 \%$ confluence. The cells were then washed with MEM and incubated with the respective inhibitors at $25^{\circ} \mathrm{C}$ for $30 \mathrm{~min}$ before bacterial inoculation. The mixture was centrifuged for $5 \mathrm{~min}$ at $800 \mathrm{~g}$ at $4{ }^{\circ} \mathrm{C}$ and the plate was incubated for a further $30 \mathrm{~min}$ at $25^{\circ} \mathrm{C}$. The wells were washed once with MEM to remove bacteria remaining in the medium and incubated for $30 \mathrm{~min}$ with MEM containing gentamicin $\left(100 \mu \mathrm{g} \mathrm{ml}^{-1}\right)$ to kill any residual extracellular bacteria. The EPC cells were washed three times with MEM to remove any remaining gentamicin that could kill bacteria subsequently released from cells. Triton X-100 (1 ml, $1 \%)$ was added to each well to lyse the EPC cells and dilution series were plated on TSA to determine the number of viable intracellular bacteria. The invasion rate was calculated as a mean of three trials in triplicate TSA plates.

Statistical analysis. All results from morphological and invasion assays were expressed as means \pm SD. The data from these assays were analysed using one-way ANOva followed by a Duncan multiple range test (SAS software). A value of $P<0.05$ was considered to be significant.

\section{RESULTS}

\section{Morphological changes of EPC cells induced by $A$ hydrophila}

Upon infection with the virulent $A$. bydrophila strain PPD134/91, EPC cells underwent a series of morphological changes empirically described as stages I-III. An uninfected monolayer of EPC cells appeared as a smooth sheet with the cells adhering tightly to their neighbours (Fig. 1a). In stage I (43 min post-infection), the cells became slightly detached from one another (Fig. 1b). The smooth appearance was lost and the cells appeared darker. In stage II (58 min post-infection), the separation between cells became more apparent, large holes separated cells (about $50 \%$ of the cells remained attached to the tissue culture plate) and they were elongated to form long spindles (Fig. 1c). In stage III (about $90 \mathrm{~min}$ post-infection), the cells became rounded and the spindle connections were lost (Fig. 1d). Bacteria enclosed in a vacuole could be seen in the cells but no other cellular organelle was visible (Fig. 1g).

\section{Effects of $\boldsymbol{A}$. hydrophila on F-actin distribution}

The distribution of microfilaments (F-actin) was also examined during $A$. bydrophila infection. In the control EPC cells, F-actin was arranged in a network and stress fibres were seen (Fig. 2a). Cells that were infected with PPD134/91 had localization of F-actin (actin clouds) (Fig. 2b). These actin clouds were observed in stages I and II but not in stage III of infected cells (data not shown).

\section{Screening of signal transduction inhibitors}

Different classes of inhibitors were screened to better understand the signal transduction pathway used by $A$. bydrophila when entering EPC cells. The times taken to reach the respective stages were recorded for each inhibitor. Stage II was chosen as an end point in scoring because of the clarity of the morphological changes. Among all the inhibitors used for screening, only genistein, a tyrosine kinase inhibitor, delayed the time taken for induction of morphological changes in EPC cells (Fig. 1f), whereas staurosporine, a protein kinase $C$ inhibitor, and sodium orthovanadate, a protein tyrosine phosphatase inhibitor, decreased the time taken for changes to occur (Table 1). Staurosporine accelerated the morphological changes of EPC cells to a greater extent than sodium orthovanadate (Table 1 and Fig. 1e). Inhibitors alone did not induce any morphological changes in control EPC cells.

\section{Concentration effects of genistein}

The effect of increasing concentrations of genistein on internalization of $A$. bydrophila was examined by measuring the time taken for the EPC cells to reach stage 

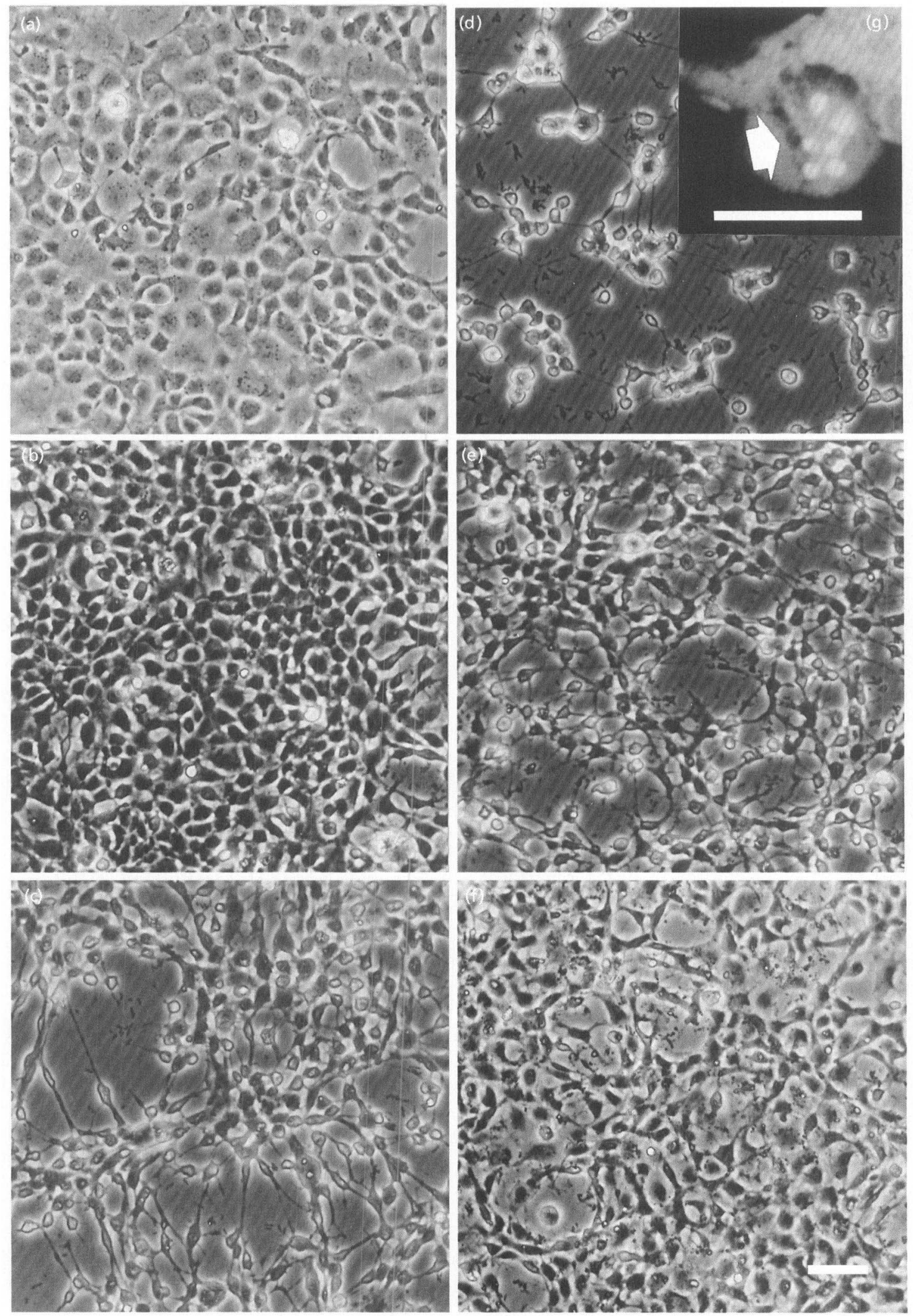

Fig. 1. Phase-contrast and confocal micrographs of EPC cells infected with $A$. hydrophila PPD134/91. Different stages of infection and treatments are included. (a) Uninfected control; (b) stage I of infection ( $43 \mathrm{~min}$ ); (c) stage II of infection ( $58 \mathrm{~min})$; ( $\mathrm{d}, \mathrm{g})$ stage III of infection $(70 \mathrm{~min})$; (e) $43 \mathrm{~min}$ with $0.005 \mu \mathrm{M}$ staurosporine; and (f) $58 \mathrm{~min}$ with $250 \mu \mathrm{M}$ genistein. In (g) A. hydrophila was stained using the Live/Dead BacLight Viability kit. Bacteria were seen inside the distorted and ghost-like EPC cells as indicated by the arrow in (g). Bar in (f) (also applies to a-e), $15 \mu \mathrm{m}$; bar in (g), $10 \mu \mathrm{m}$. 

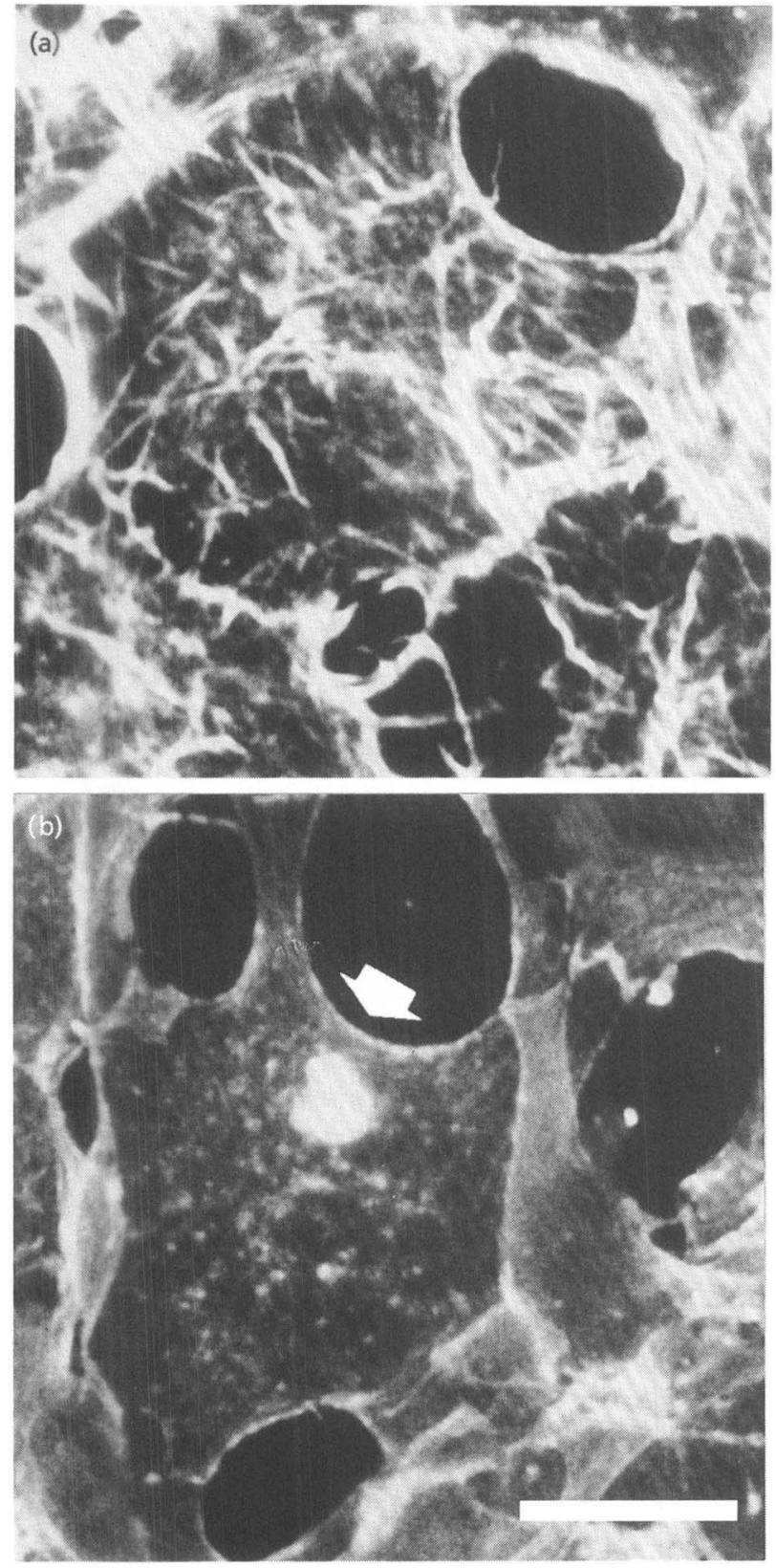

Fig. 2. F-actin-stained confocal micrographs of EPC cells infected with $A$. hydrophila PPD134/91. (a) Uninfected control; (b) stage I of infection. In the control EPC cells, F-actin was arranged in a network and stress fibres were seen. Actin clouds were visible during stage 1 of infection (marked by white arrow). Bar, $5 \mu \mathrm{m}$.

I and stage II morphology (Fig. 3) and by measuring the number of bacteria internalized (Fig. 4). With increasing concentrations of genistein, the time taken for EPC cells to reach stage II morphology was significantly increased $(P<0.05)$ (Figs 1f and 4). Genistein $(50 \mu \mathrm{M})$ had negligible effect on the morphological effects of PPD134/ 91 on EPC cells. However, with increasing concentrations of genistein from $100 \mu \mathrm{M}$ to $250 \mu \mathrm{M}$, times taken to reach stages I and II increased significantly (Fig.

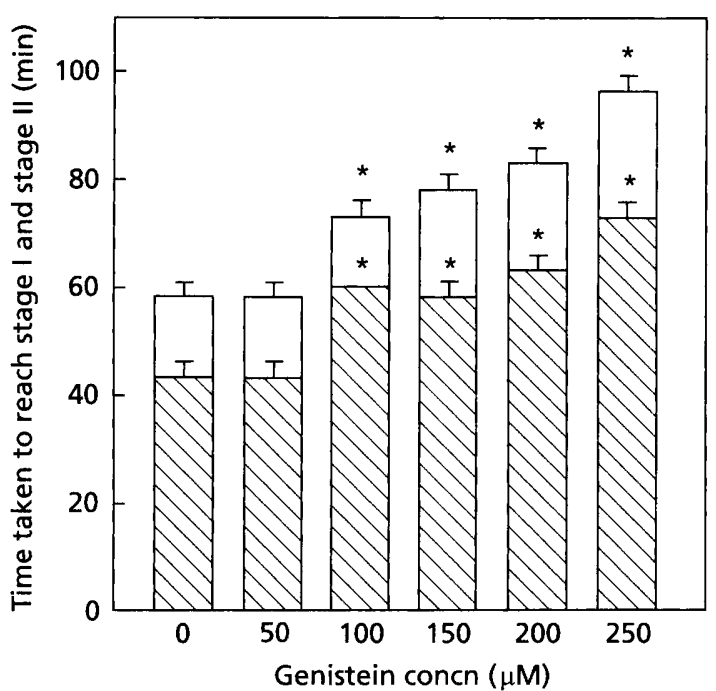

Fig. 3. Effect of different concentrations of genistein on morphological changes of EPC cells induced by $A$. hydrophila PPD134/91. Stage I (hatched bars) was defined as the time when the EPC cells became slightly detached from one another. The smooth appearance was lost and the cells appeared darker in colour. Stage II (open bars) was defined as the time when larger holes separate infected cells and about $50 \%$ of the cells remained on the tissue culture plate. The infected EPC cells were elongated to form long spindles. Values shown are the mean \pm SD from duplicate wells in three separate experiments for each sample. Those concentrations where the time taken to reach stage II was significantly different from that in control cultures $(P<0.05)$ are marked with asterisks.

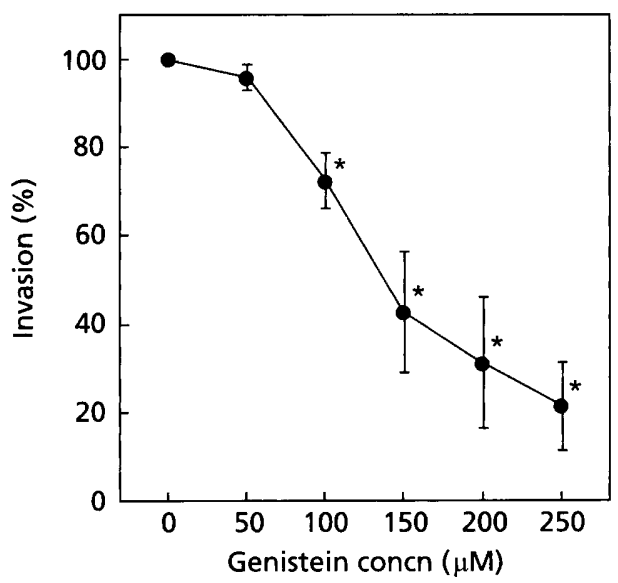

Fig. 4. Effect of different concentrations of genistein on invasion rate in EPC cells. Values shown are the mean \pm SD of three experiments in triplicate TSA plates for each sample. Those concentrations where the invasion rate was significantly different from that in control cultures $(P<0.05)$ are marked with asterisks.

3). In the presence of $250 \mu \mathrm{M}$ genistein, infected EPC cells took 30 min longer than the control cells to reach stage I morphology and 41 min longer to reach stage II morphology. The time interval between the start of 
Table 2. Effect of addition of genistein at various time points after infection with A. hydrophila PPD134/91

Values shown are the mean $\pm \mathrm{sD}$ from duplicate wells in three separate experiments.

\begin{tabular}{|lcccccc|}
\hline \multirow{2}{*}{$\begin{array}{l}\text { Genistein } \\
\text { concn }(\boldsymbol{\mu M})\end{array}$} & $\mathbf{5} \mathbf{~ m i n}$ & $\mathbf{1 0} \mathbf{~ m i n}$ & $\mathbf{1 5} \mathbf{~ m i n}$ & $\mathbf{2 0} \mathbf{~ m i n}$ & $\mathbf{3 0} \mathbf{~ m i n}$ & $\mathbf{4 5} \mathbf{~ m i n}$ \\
\cline { 2 - 7 } & & & & & & \\
\hline 0 & $58 \cdot 3 \pm 2 \cdot 9$ & $58 \cdot 3 \pm 2 \cdot 9$ & $58 \cdot 3 \pm 2 \cdot 9$ & $61 \cdot 7 \pm 7 \cdot 6$ & $61 \cdot 7 \pm 7 \cdot 6$ & $55 \cdot 0 \pm 5 \cdot 0$ \\
50 & $58 \cdot 3 \pm 2 \cdot 9$ & $60 \cdot 0$ & $58 \cdot 3 \pm 2 \cdot 9$ & $61 \cdot 7 \pm 7 \cdot 6$ & $61 \cdot 7 \pm 7 \cdot 6$ & $55 \cdot 0 \pm 5 \cdot 0$ \\
100 & $70 \cdot 0 \pm 5 \cdot 0^{*}$ & $66 \cdot 7 \pm 2 \cdot 9$ & $61 \cdot 7 \pm 2 \cdot 9$ & $65 \cdot 0 \pm 5 \cdot 0$ & $61 \cdot 7 \pm 7 \cdot 6$ & $55 \cdot 0 \pm 5 \cdot 0$ \\
150 & $75 \cdot 0 \pm 5 \cdot 0^{*}$ & $70 \cdot 0 \pm 5 \cdot 0^{*}$ & $65 \cdot 0 \pm 5 \cdot 0^{* *}$ & $70 \cdot 0 \pm 5 \cdot 0$ & $68 \cdot 3 \pm 7 \cdot 6$ & $55 \cdot 0 \pm 5 \cdot 0$ \\
200 & $80 \cdot 0 \pm 5 \cdot 0^{*}$ & $76 \cdot 7 \pm 7 \cdot 6^{*}$ & $71 \cdot 7 \pm 2 \cdot 9^{* *}$ & $75 \cdot 0 \pm 5 \cdot 0^{*}$ & $68 \cdot 3 \pm 7 \cdot 6$ & $55 \cdot 0 \pm 5 \cdot 0$ \\
250 & $85 \cdot 0 \pm 5 \cdot 0^{*}$ & $80 \cdot 0 \pm 9 \cdot 0^{*}$ & $76 \cdot 7 \pm 2 \cdot 9^{*}$ & $78 \cdot 3 \pm 2 \cdot 9^{*}$ & $71 \cdot 7 \pm 7 \cdot 6$ & $55 \cdot 0 \pm 5 \cdot 0$ \\
\hline
\end{tabular}

* Those concentrations where the time taken to reach stage II was significantly different from that in control cultures $(P<0.05)$.

stage I and the start of stage II was not significantly affected by the increasing concentrations of genistein $(P>0.05)$.

The number of bacteria internalized in the presence of different concentrations of genistein was compared to an untreated control, which was taken to be $100 \%$. Similar concentration-dependent inhibitory effects of genistein were observed in this invasion assay as in the morphological studies. The number of intracellular bacteria decreased with increasing concentrations of genistein. At $50 \mu \mathrm{M}$ genistein there was no apparent effect on the number of internalized bacteria, whereas at $250 \mu \mathrm{M}$ genistein the number of bacteria internalized were reduced to $23 \%$ of the control cultures (Fig. 4). For all subsequent experiments, morphological assays (time taken to reach stage II) were used to study the effects of inhibitors on the interaction between PPD134/91 and EPC cells as they were easier to perform and correlated well with the internalization assay.

The ability of genistein to delay the effects of PPD134/91 on EPC cells that were already infected with bacteria was investigated by adding different concentrations of genistein at 5, 10, 15, 20, 30 and 45 min after infection of cells (Table 2). It appeared that morphological changes could be delayed by genistein for the first $20 \mathrm{~min}$ after infection. If applied $20 \mathrm{~min}$ after infection, only the higher concentrations of genistein $(250$ and $200 \mu \mathrm{M})$ significantly $(P<0.05)$ delayed morphological changes (Table 2). If applied $30 \mathrm{~min}$ after infection, even the highest concentration of genistein $(250 \mu \mathrm{M})$ failed to delay the effects of PPD134/91 on EPC cells.

\section{Effects of inhibitors on the functions of PPD134/91 and EPC cells}

The viability of $A$. bydrophila PPD134/91 treated with genistein $(250 \mu \mathrm{M})$, staurosporine $(0.005 \mu \mathrm{M})$ or sodium orthovanadate $(10 \mu \mathrm{M})$ in MEM for $3 \mathrm{~h}$ was $96.9 \pm$ $3.3 \%, 94.5 \pm 6.4 \%$ or $104.1 \pm 7.9 \%(n=3)$ of untreated controls, respectively. Hence genistein did not interfere with bacterial viability. The viability of EPC cells treated with genistein $(250 \mu \mathrm{M})$, staurosporine $(0.005 \mu \mathrm{M})$ or sodium orthovanadate $(10 \mu \mathrm{M})$ in MEM for $3 \mathrm{~h}$ was $100 \%(n=3)$ of untreated controls. Thus, genistein does not interfere with the viability of EPC cells.

To determine whether genistein permanently reduced the ability of $A$. hydrophila to induce changes in EPC cells, the bacteria were incubated with $250 \mu \mathrm{M}$ genistein for $30 \mathrm{~min}$, washed and used to infect EPC cells. The time taken to reach stage II morphology $(57 \pm 2 \mathrm{~min})$ was similar to that seen with the untreated bacteria (58 $\pm 3 \mathrm{~min})$. Hence genistein did not impair the ability of $A$. bydrophila to induce morphological changes. To determine whether genistein permanently affected host cells, EPC cells were incubated with $250 \mu \mathrm{M}$ genistein for $30 \mathrm{~min}$. After the genistein was removed by washing, PPD134/91 induced stage II morphology in treated EPC cells at the same time ( $58 \pm 1 \mathrm{~min})$ as untreated controls $(58 \pm 3 \mathrm{~min})$. Hence the effects of genistein on EPC cells are reversible. Similar results were found for staurosporine and sodium orthovanadate (data not shown).

\section{Effects of daidzein on internalization}

Daidzein is an inactive analogue of genistein, and does not inhibit the activity of tyrosine kinase. To confirm that genistein specifically inhibited the action of tyrosine kinase, the effect of daidzein on the time taken to reach stage II was examined. It was found that daidzein had no significant effect on the morphological changes in EPC cells induced by $A$. bydrophila (Table 1).

\section{Effects of inhibitors on other virulent strains}

The effects of the different signal transduction inhibitors on two other virulent strains of A. bydrophila, PPD122/ 91 and PPD11/90, were also examined. Genistein significantly delayed the time taken for induction of morphological changes in the EPC cells by either PPD122/91 or PPD11/90. In contrast, staurosporine 
Table 3. Effects of inhibitors on morphological changes of EPC induced by other virulent strains of $A$. hydrophila

\begin{tabular}{|lcc|}
\hline Inhibitor & \multicolumn{2}{c|}{ Time taken to reach stage II $(\mathbf{m i n})^{*}$} \\
\cline { 2 - 3 } & Strain PPD122/91 & Strain PPD11/90 \\
\hline Control & $93 \cdot 3 \pm 2 \cdot 9$ & $51 \cdot 7 \pm 2 \cdot 9$ \\
Genistein, $50 \mu \mathrm{M}$ & $93 \cdot 3 \pm 2 \cdot 9$ & $51 \cdot 7 \pm 2 \cdot 9$ \\
Genistein, $100 \mu \mathrm{M}$ & $103 \cdot 3 \pm 5 \cdot 8 \dagger$ & $61 \cdot 7 \pm 10 \cdot 4 \dagger$ \\
Genistein, $150 \mu \mathrm{M}$ & $105 \cdot 0 \pm 5 \cdot 0 \dagger$ & $71 \cdot 7 \pm 2 \cdot 9 \dagger$ \\
Genistein, $200 \mu \mathrm{M}$ & $106 \cdot 7 \pm 2 \cdot 9 \dagger$ & $76 \cdot 7 \pm 2 \cdot 9 \dagger$ \\
Genistein, $250 \mu \mathrm{M}$ & $110 \cdot 0 \dagger$ & $83 \cdot 8 \pm 2 \cdot 9 \dagger$ \\
Staurosporine, $5 \mathrm{nM}$ & $81 \cdot 7 \pm 2 \cdot 9 \dagger$ & $45 \cdot 0 \dagger$ \\
\hline
\end{tabular}

*Values shown are the mean \pm SD from duplicate wells in three separate experiments.

$\dagger$ Those inhibitors where the time taken to reach stage II was significantly different from the control $(P<0 \cdot 05)$.

decreased the time taken for the changes to occur (Table 3).

\section{DISCUSSION}

Genistein was found to inhibit the rate of morphological changes induced by $A$. hydrophila, whereas staurosporine and sodium orthovanadate accelerated it (Table 1). Genistein is a specific inhibitor of tyrosine kinase, with negligible effect on the activity of serine and threonine kinases (Akiyama et al., 1987), whereas sodium orthovanadate is an inhibitor of protein tyrosine phosphatase (Leis \& Kaplan, 1982). Because the effects of genistein and sodium orthovanadate are consistent with their antagonistic enzymic actions, it is likely that tyrosine kinase is involved in interactions between $A$. hydrophila and EPC cells. Staurosporine is known to inhibit protein kinase $\mathrm{C}$ in vitro and increases tyrosine phosphorylation in PC12 cells (Rasouly \& Lazarovici, 1994). Therefore, the accelerated rate of morphological change produced by staurosporine might be associated with enhanced tyrosine phosphorylation. Verapamil and nifedipine are $\mathrm{Ca}^{2+}$ channel blockers (Varadi et al., 1995). Our data show that both verapamil and nifedipine failed to block the morphological changes induced by PPD134/91 in EPC cells, suggesting that the internalization process is not mediated by $\mathrm{Ca}^{2+}$ influx through voltage-dependent $\mathrm{Ca}^{2+}$ channels. Likewise, calphostin $\mathrm{C}$, a potent protein kinase $\mathrm{C}$ inhibitor (Kobayashi et al., 1989), and okadaic acid and calyculin A, inhibitors of protein phosphatase (Ishihara et al., 1989), did not alter the morphological changes induced by PPD134/91, indicating that the protein kinase $\mathrm{C}$ pathway of signal transduction might not be involved in the bacterial internalization process.

On the basis of these results it appears that a tyrosine kinase is involved in the signalling pathway between $A$. bydrophila and the EPC cells. Genistein also inhibits bacterial invasion in Listeria monocytogenes (Tang et al., 1994) and enteropathogenic E. coli (Rosenshine et al., 1992b). Genistein, staurosporine and sodium orthovanadate could affect internalization by other nonselective mechanisms, including affecting bacterial viability or some bacterial function needed for internalization or the functions of EPC cells. Each of these possibilities was examined and the data show that these inhibitors did not affect the bacteria and the EPC cells in a non-specific manner. Thus, these inhibitors appear to act primarily by specifically affecting bacterial internalization.

Genistein was able to reduce morphological changes for up to 20 min after infection. Twenty minutes may be the time required for signal transduction initiated by tyrosine kinase to transmit to downstream signalling molecules and once this has been achieved the bacterial internalization process is irreversible (Table 2). The time taken from stage I to stage II was not significantly different $(P>0.05)$ with increasing concentrations of genistein (Fig. 3). This suggests that on reaching a stage I morphology ( $43 \mathrm{~min}$ for control cells), the signal generated by tyrosine kinase has already been transduced to a downstream level that cannot be blocked by a tyrosine kinase inhibitor, such as genistein.

Daidzein is an inactive analogue of genistein that does not inhibit the action of tyrosine kinase. We found that daidzein had no significant effect on the invasion rate of A. bydrophila on EPC cells. This further supports the hypothesis that genistein blocks $A$. bydrophila internalization specifically by tyrosine kinase inhibition.

\section{Signal transduction pathway of $\boldsymbol{A}$. hydrophila}

Our results suggest that there is a signal transduction pathway participating in the interaction between the pathogen A. hydrophila and EPC cells. It is likely that $A$. bydrophila adheres to the host cell surface before internalization. The adhesins may be the $\mathrm{O}$-antigen of lipopolysaccharide (Merino et al., 1996) or the outermembrane protein isolated by Lee et al. (1997) which 
mediate the adhesion and internalization of the bacterium. At present it is not clear whether A. bydrophila also produces invasin(s) to aid in internalization.

After adhesion, A. bydrophila probably initiates a signalling cascade that involves tyrosine kinase. Hence this kinase appears to function as part of an uptake signal for this fish pathogen. At the end of the signalling pathway, A. bydrophila causes the rearrangement of microfilament (F-actin) in EPC cells to form actin clouds (Fig. 2). These actin clouds might be associated with the internalization of bacteria. Subsequently, the internalized bacteria replicate intracellularly and cause morphological changes in the EPC monolayer.

Our previous report suggested that PPD134/91, PPD122/91 and PPD11/90 were the three major serogroups among our Southeast Asia isolates of A. bydrophila (Leung et al., 1995). By screening the same repertoire of signal transduction inhibitors, we have found that a common signal transduction pathway was shared by all serogroups (Table 3). A. hydrophila is believed to be a very heterogeneous species with different surface characteristics (Mittal et al., 1980), which presents a potential problem for vaccine development (Stevenson, 1988). If A. hydrophila uses a common invasion and internalization pathway, new approaches could be designed to specifically block this common signal transduction process for use in treatment and prophylaxis.

\section{ACKNOWLEDGEMENTS}

The authors are grateful to the National University of Singapore (K.Y.L.) and the National Medical Research Council (W.S.F.W.) for providing research grants for this work. We would like to thank Dr W. K. Chan for providing us with the EPC cells. We also wish to thank Drs T. T. Ngiam and H. Loh (the Primary Production Department of Singapore) for providing us with the A. hydrophila isolates. We are grateful to $\mathrm{Mr} \mathrm{H}$. K. Yip for taking the photographs.

\section{REFERENCES}

Akiyama, T., Ishida, J., Nakagawa, S., Ogawara, H., Watanabe, S., Itoh, N., Shibuya, M. \& Fukami, Y. (1987). Genistein, a specific inhibitor of tyrosine-specific protein kinases. $J$ Biol Chem 262, 5592-5595.

Allan, B. J. \& Stevenson, R. M. W. (1981). Extracellular virulence factors of Aeromonas bydrophila in fish infections. Can $J$ Microbiol 27, 1114-1122.

Ascencio, F., Ljungh, A. \& Wadstrom, T. (1991). Comparative study of extracellular matrix protein building to Aeromonas bydrophila isolated from diseased fish and human infection. Microbios 77, 47-55.

Atkinson, H. M. \& Trust, T. J. (1980). Hemagglutination properties and adherence ability of Aeromonas hydrophila. Infect Immun 27, 938-946.

Burke, J. \& Rogers, L. (1981). Identification of pathogenic bacteria associated with the occurrence of 'red spot' in sea mullet, Mugil cephalus, in south-eastern Queensland. J Fish Dis 4, 153-159.

Dooley, J. S. G. \& Trust, T. J. (1988). Surface protein composition of Aeromonas hydrophila strains virulent for fish: identification of a surface array protein. J Bacteriol 170, 499-506.

Finlay, B. B. \& Falkow, S. (1989). Common themes in microbial pathogenicity. Microbiol Rev 53, 210-230.

Finlay, B. B., Ruschkowski, S. \& Dedhar, S. (1991). Cytoskeletal rearrangements accompanying Salmonella entry into epithelial cells. J Cell Sci 99, 283-296.

Garcia-del Portillo, F., Zwick, M. B., Leung, K. Y. \& Finlay, B. B. (1993). Salmonella induces the formation of filamentous structures containing lysosomal membrane glycoproteins in epithelial cells. Proc Natl Acad Sci USA 90, 10544-10548.

Hale, T. L. \& Boventre, P. F. (1979). Shigella infection of Henle intestinal epithelial cells: role of bacterium. Infect Immun 32, 137-144.

Ishihara, H., Martin, B. L., Brautigan, D. L. \& 7 other authors (1989). Calyculin A and okadaic acid: inhibitors of protein phosphatase activity. Biochem Biophys Res Commun 159, 871877.

Kobayashi, E., Nakano, H., Morimoto, M. \& Tamaoki, T. (1989). Calphostin C (UCN-1028C), a novel microbial compound, is a highly potent and specific inhibitor of protein kinase C. Biochem Biophys Res Commun 159, 548-553.

Lee, S. Y., Yin, Z., Ge, R. \& Sin, Y. M. (1997). Isolation and characterization of fish Aeromonas bydrophila adhesins important for in vitro epithelial cell invasion. J Fish Dis 20, 169-175.

Leis, J. F. \& Kaplan, N. O. (1982). An acid phosphatase in the plasma membranes of human extracytoma showing marked specificity toward phosphotyrosine protein. Proc Natl Acad Sci USA 79, 6507-6511.

Leung, K. Y. \& Finlay, B. B. (1991). Intracellular replication is essential for the virulence of Salmonella typhimurium. Proc Natl Acad Sci USA 88, 11470-11474.

Leung, K. Y. \& Stevenson, R. M. W. (1988). Characteristics and distribution of extracellular proteases from Aeromonas bydrophila. J Gen Microbiol 134, 151-160.

Leung, K. Y., Yeap, I. V., Lam, T. J. \& Sin, Y. M. (1995). Serum resistance as a good indicator for virulence in Aeromonas bydrophila strains isolated from diseased fish in South-East Asia. $J$ Fish Dis 18, 511-518.

Leung, K. Y., Lim, T. M., Lam, T. J. \& Sin, Y. M. (1996). Morphological changes in carp epithelial cells infected with Aeromonas bydrophila. J Fish Dis 19, 167-174.

Ljungh, A. \& Wadstrom, T. (1982). Aeromonas toxins. Pharmacol Ther 15, 339-354.

Low, K. W., Goh, S. G., Lim, T. M., Sin, Y. M. \& Leung, K. Y. (1998). Actin rearrangements accompanying Aeromonas bydrophila entry into cultured fish cells. J Fish Dis 21, (in press).

Merino, S., Rubires, X., Aguilar, A. \& Tomas, J. M. (1996). The O:34-antigen lipopolysaccharide as an adhesin in Aeromonas bydrophila. FEMS Microbiol Lett 139, 97-101.

Mittal, K. R., Lalonde, G., LeBlanc, D., Olivier, G. \& Lallier, R. (1980). Aeromonas bydrophila in rainbow trout: relation between virulence and surface characteristics. Can J Microbiol 26, 1501-1503.

Moulder, J. W. (1985). Comparative biology of intracellular parasitism. Microbiol Rev 49, 298-337.

Neves, M. S., Nunes, M. P. \& Milhomem, A. M. (1994). Aeromonas species exhibit aggregative adherence to Hep-2 cells. $J$ Clin Microbiol 32, 1130-1131.

Newman, S. G. (1993). Bacterial vaccines for fish. Annu Rev Fish Dis 3, 145-185. 
Nieto, T. P., Corcobada, M. J. R., Toranzao, A. E. \& Berja, J. L. (1985). Relation of water temperature to infection of Salmo gairdneri with Aeromonas. Fish Pathol 20, 99-105.

Pace, J., Hayman, M. J. \& Galan, J. E. (1993). Signal transduction and invasion of epithelial cells by S. typhimurium. Cell 72, 505-514.

Pippy, J. H. C. \& Hare, G. M. (1969). Relationship of river pollution to bacterial infection in salmon (Salmo salar) and suckers (Catostomus commersoni). Trans Am Fish Soc 4, 685-690.

Popoff, M. (1984). Aeromonas. In Bergey's Manual of Systematic Bacteriology, vol. 1, pp. 545-548. Edited by N. R. Krieg. Baltimore, MD: Williams \& Wilkins.

Rasouly, D. \& Lazarovici, P. (1994). Staurosporine induces tyrosine phosphorylation of a $145 \mathrm{KDa}$ protein but does not activate gp140 ${ }^{\text {trk }}$ in PC12 cells. Eur J Pharmacol 269, 255-264.

Roberts, R. J., Furich, G. N. \& Millan, S. D. (1992). Epizootic ulcerative syndrome: the current position. In Diseases in Asian Aquaculture, vol. 1, pp. 431-436. Edited by M. Shariff, R. P. Subasinghe \& J. R. Arthur. Manila: Fish Health Section, Asian Fisheries Society.

Rosenshine, I. \& Finlay, B. B. (1993). Exploitation of host signal transduction pathways and cytoskeletal functions by invasive bacteria. BioEssays 15, 17-24.

Rosenshine, I., Donnenberg, M. S., Kaper, J. B. \& Finlay, B. B. (1992a). Signal transduction between enteropathogenic Escherichia coli (EPEC) and epithelial cells, EPEC induces tyrosine phosphorylation of host cell proteins to initiate cytoskeletal rearrangement and bacteria uptake. EMBO J 11, 3551-3560.

Rosenshine, I., Duronio, V. \& Finlay, B. B. (1992b). Tyrosine protein kinase inhibitors block invasin-promoted bacterial uptake by epithelial cells. Infect Immun 60, 2211-2217.

Rosenshine, I., Ruschkowski, S., Stein, M., Reinscheid, D. J., Mills, S. D. \& Finlay, B. B. (1996). A pathogenic bacterium triggers epithelial signals to form a functional bacterial receptor that mediates actin pseudopod formation. EMBO J 15, 2613-2624.

Stevenson, R. M. W. (1988). Vaccination against Aeromonas hydrophila. In Fish Vaccination, pp. 112-123. Edited by A. E. Ellis. New York: Academic Press.

Tang, P., Rosenshine, I. \& Finlay, B. B. (1994). Listeria monocytogenes, an invasive bacterium, stimulates MAP kinase upon attachment to epithelial cells. Mol Cell Biol 5, 455-464.

Thune, R. L., Stanley, L. A. \& Cooper, K. (1993). Pathogenesis of Gram-negative bacterial infections in warm water fish. Annu Rev Fish Dis 3, 37-68.

Varadi, G., Mori, Y., Mikala, G. \& Schwartz, A. (1995). Molecular determinants of $\mathrm{Ca}^{2+}$ channel function and drug action. Trends Pharmacol Sci 16, 43-49.

Wolf, K. \& Mann, J. A. (1980). Poikilotherm vertebrate cell lines and viruses: a current listing for fishes. In Vitro 16, 168-179.

Yadav, M., Indira, G. \& Ansary, A. (1992). Cytotoxin elaboration by Aeromonas hydrophila isolated from fish with epizootic ulcerative syndrome. J Fish Dis 15, 183-189.

Young, V. V., Falkow, S. \& Schoolnik, G. K. (1992). The invasion protein of Yersinia enterocolitica: internalization of invasinbearing bacteria by eukaryotic cells is associated with reorganization of the cytoskeleton. J Cell Biol 116, 197-207.

Received 7 April 1997; revised 29 July 1997; accepted 17 October 1997. 